\title{
Behavior of Bradyrhizobium japonicum Strains Under Different Herbicide Concentrations ${ }^{1}$
}

\author{
Comportamento de Estirpes de Bradyrhizobium japonicum em Diferentes Concentrações de \\ Herbicidas
}

\begin{abstract}
ARRUDA, J.S. ${ }^{2}$, LOPES, N.F. ${ }^{3}$ e MOURA, A.B. ${ }^{4}$
RESUMO - As estirpes de Bradyrhizobium japonicum SEMIA 5073, SEMIA 5074, SEMIA 5079 e SEMIA 5080 foram cultivadas in vitro, utilizando meio de Vincent acrescido de diferentes doses dos herbicidas imazaquin $\left(0 ; 0,04 ; 0,12 ; 0,24 ; 0,36 \mu \mathrm{g}\right.$ i.a. $\left.\mathrm{g}^{-1}\right)$, clomazone $(0 ; 0,4 ; 0,8$; 1,$6 ; 3,2 \mu$ i.a. $\left.\mathrm{g}^{-1}\right)$ e sulfentrazone $\left(0 ; 0,2 ; 0,4 ; 0,8 ; 1,6 \mu \mathrm{g}\right.$ i.a. $\left.\mathrm{g}^{-1}\right)$, com o objetivo de avaliar a tolerância destas estirpes aos herbicidas. Os três herbicidas afetaram drasticamente as estirpes de rizóbio testadas, causando decréscimo significativo no crescimento ou na sobrevivência, em função do incremento nas doses. As estirpes de rizóbio apresentaram tolerância diferenciada aos herbicidas. As doses de herbicidas que reduziram em $50 \%$ o crescimento ou a sobrevivência das estirpes $\left(\mathrm{I}_{50}\right)$ foram inferiores àquelas recomendadas para o controle de plantas daninhas na cultura de soja, para os três herbicidas estudados; no entanto, o $\mathrm{I}_{50}$ do herbicida sulfentrazone foi significativamente menor que o $\mathrm{I}_{50}$ dos herbicidas imazaquin e clomazone.
\end{abstract}

Palavras-chave: rizóbio, clomazone, imazaquin, sulfentrazone.

\begin{abstract}
The Bradyrhizobium japonicun strains SEMIA 5073, SEMIA 5074, SEMIA 5079 and SEMIA 5080 were grown in vitro using Vincent medium combined with different rates of the herbicides imazaquin $\left(0,0.04,0.12,0.24,0.36 \mu g\right.$ a.i. $\left.g^{-1}\right)$, clomazone $(0,0.4,0.8,1.6$ and $3.2 \mu \mathrm{g}$ a.i. $\left.\mathrm{g}^{-1}\right)$ and sulfentrazone $\left(0,0.2,0.4,0.8\right.$ and $1.6 \mu \mathrm{g}$ a.i. $\left.\mathrm{g}^{-1}\right)$ to evaluate the strains tolerance to herbicides. The three herbicides drastically inhibited all the rhizobium strains tested, showing a significant decrease of the CFU number as a function of herbicide rates. The rhizobium strains presented a differentiated tolerance to the herbicides. The herbicide rates that reduced $50 \%\left(I_{50}\right)$ of the growth or survival of the rhizobium strains were below the recommended sprayed rates for weed control in the soybean crop, for all the three herbicides studied; however, sulfentrazone $I_{50}$ was smaller than imazaquin and clomazone $I_{50}$.
\end{abstract}

Key words: rhizobium, clomazone, imazaquin, sulfentrazone.

\section{INTRODUCTION}

The use of herbicides is an important component of the production process of most crops, mainly those capable of fixing atmospheric nitrogen. The fixation of the dinitrogen through soybean-rhizobium symbiosis helps with over
$70 \%$ in the requirement of total $\mathrm{N}$ of the culture (Marenco et al., 1993; Thurlow \& Hiltbold, 1985). However, the use of herbicides can reduce nodulation (Bollich et al., 1988; Deuber et al., 1981; Mallik \& Tesfai, 1985; Varela \& Cruz, 1984). This reduction in the $\mathrm{N}_{2}$ fixation caused by the herbicides can be due to the

\footnotetext{
Recebido para publicação em 14/1/2000 e na forma revisada em 26/1/2001.

Pós-graduando do Dep. de Fitossanidade, FAEM/UFPEL, 96010-900 Pelotas, RS; ${ }^{3}$ Professor do Dep. de Botânica e pesquisador
} do CNPq, UFPEL; ${ }^{4}$ Professora do Dep. de Fitossanidade e pesquisadora do CNPq, FAEM/UFPEL, <abmoura@ufpel.tche.br>. 
indirect action on the plant growth or to direct interference on the growth of the rhizobium or upon the plant-rhizobium association.

Some herbicides of the dinitroanilines group can indirectly reduce the nodulation, by reducing plant growth (Alagawagi \& Reddy, 1985; Brock, 1972; Peters \& Zbiba, 1979). Marenco et al. (1993) observed reductions in nodulation and nitrogen fixation of soybean plants treated with chlorimuron and clomazone. These reductions in the fixation of $\mathrm{N}_{2}$ were attributed to the effects of the herbicides on the growth of the plant, without, however, eliminating the possibility of some direct effect of those herbicides on the growth of the rhizobium.

The herbicides traditionally used for the control of weeds in the soybean culture do not seem to inhibit the growth of the rhizobium in culture medium (Alagawagi \& Reddy, 1985; Kishinevski et al., 1988; Moorman, 1986). However, there are evidences that some products, used in usual concentrations for weed control in soybean culture, can reduce the growth in vitro of several strains of rhizobium (Borges et al., 1990).

This experiment was carried out to obtain information on the effect of dosages of the herbicides clomazone, imazaquin and sulfentrazone on the growth of Bradyrhizobium japonicum strains in vitro.

\section{MATERIAL AND METHODS}

The rhizobium strains SEMIA 5073, SEMIA 5074, SEMIA 5079 and SEMIA 5080 (from PESAGRO/Centro de Pesquisa de Fixação Biológica do Nitrogênio collection) were used in the experiment.

Rhizobium suspension was obtained from cultures in Vincent medium (1970) for 72 and 96 hours, with a dilution of 1: $10(\mathrm{ml})$ in saline solution $(0,85 \% \mathrm{NaCl})$, sterilized and added of triton X-100 to $0.05 \%$.

Imazaquin was added in the rates of 0 , $0.04,0.12,0.24,0.36 \mu \mathrm{g}$ a. i. $\mathrm{g}^{-1}$ to the melting Vincent medium. Clomazone and sulfentrazone were used in the rates of $0,0.4,0.8,1.6$, $3.2 \mu \mathrm{g}$ a.i. $\mathrm{g}^{-1}$ and $0,0.2,0.4,0.8,1.6 \mu \mathrm{g}$ a.i. $\mathrm{g}^{-1}$ of medium, respectively. After solidification, the medium was dried with open lids, in a biological safety cabinet.
Drops of $10 \mu \mathrm{L}$ of the different dilutions of the rhizobium suspensions were uniformly spread on the surface of the medium (Romeiro, 1996). Eight dilutions $\left(10^{-2}\right.$ to $\left.10^{-9}\right)$, with eight replications were used. Vincent medium was used without herbicides as control and the plates were incubated at $28^{\circ} \mathrm{C}$ for 72 hours.

Counting was accomplished with the aid of a stereomicroscope and the final number of colony forming units (CFU) was obtained by arithmetic mean of the eight replicates (Romeiro, 1996).

The experimental design was completely randomized in a factorial ( $4 \times 5)$ scheme, containing four rhizobium strains and different herbicide rates. The results were submitted to variance analysis and compared by Duncan's test, at 5\% level of probability. Regression analysis was accomplished.

\section{RESULTS AND DISCUSSION}

Imazaquin reduced drastically the growth of the rhizobium strains tested (Table 1), with a significant decrease on the CFU number of all rhizobium strains being observed as a function of the increment in the imazaquin rate, showing high coefficients of determination $\left(\mathrm{R}^{2}>\right.$ 0,92) (Figure 1).

Table 1 - Number of colony forming units (CFU) of Bradhyrhizobium japonicum strains from bacterial dilution $10^{-5}$, SEMIA 5080, SEMIA 5079, SEMIA 5074 and SEMIA 5073, as a function of imazaquin doses

\begin{tabular}{|c|r|r|r|r|}
\hline \multirow{2}{*}{$\begin{array}{c}\text { DOSE } \\
\left(\mu \text { g a.i. } \mathrm{g}^{-1}\right)\end{array}$} & \multicolumn{4}{|c|}{$\mathrm{CFU}\left(\mathrm{x} 10^{7} \mathrm{ml}^{-1}\right)$} \\
\cline { 2 - 5 } & $\mathrm{S} 5080$ & $\mathrm{~S} 5079$ & $\mathrm{~S} \mathrm{5074}$ & \multicolumn{1}{c|}{5073} \\
0.00 & $1.180 \mathrm{Aa}$ & $282 \mathrm{Ab}$ & $134 \mathrm{Ac}$ & $130 \mathrm{Ac}$ \\
0.04 & $1.030 \mathrm{Aa}$ & $181 \mathrm{Bb}$ & $85 \mathrm{Bc}$ & $70 \mathrm{Bc}$ \\
0.12 & $690 \mathrm{Ba}$ & $146 \mathrm{Cb}$ & $59 \mathrm{Cc}$ & $54 \mathrm{Cc}$ \\
0.24 & $420 \mathrm{Ca}$ & $91 \mathrm{Db}$ & $37 \mathrm{Dc}$ & $35 \mathrm{Dc}$ \\
0.36 & $360 \mathrm{Ca}$ & $59 \mathrm{~Eb}$ & $26 \mathrm{Ec}$ & $25 \mathrm{Ec}$ \\
\hline
\end{tabular}

- Numbers followed by the same capital letters in the column and same small letters in the line do not differ significantly $(\mathrm{P} \leq 0.05)$ by the Duncan's test.

The indexes of reduction of $50 \%$ on the growth of number of colonies $\left(\mathrm{I}_{50}\right)$ caused by imazaquin were of $0.080,0.095,0.120$ and $0.135 \mu \mathrm{g}$ a.i. $\mathrm{g}^{-1}$ for the strains SEMIA 5073, 
SEMIA 5074, SEMIA 5079 and SEMIA 5080, respectively. Those results show that the rates that reduced $50 \%$ of the $\mathrm{CFU}$ of the strains are close to the recommended rate for the culture of the soybean, i.e., $0.12 \mu \mathrm{g}$ a.i. $\mathrm{g}^{-1}$. The strains presented a differential behavior in the in vitro growth for imazaquin, showing the following order of tolerance increase: SEMIA 5073 $<$ SEMIA $5074<$ SEMIA $5079<$ SEMIA 5080.

Those results indicated that imazaquin interferes directly in the growth or survival of the strains in vitro, acting directly in the reduction of the rhizobium CFU number. In susceptible plants, there is a marked and consistent effect of imazaquin on growth, due to inhibition of the synthesis of acetohydroxyacid synthase (AHAS), blocking the synthesis of amino acids valine, leucine and isoleucine
(Shaner et al., 1984). This inhibition reduces the protein synthesis that, in turn, interferes indirectly in DNA synthesis and cellular growth (Ray, 1984), reducing the growth rate, largely controlled by the protein synthesis.

Imazaquin effect on the rhizobium strains are not yet entirely known, but for analogy, the inhibition or reduction of the synthesis of amino acids can also be associated, for the interference in the synthesis of the AHAS enzyme, and the proteins as occur in the plants. The AHAS enzyme has been found in extracts of bacteria (Bauerle et al., 1969; Eoyang \& Silverman, 1984; Sutton et al., 1981) and archaebacteria (Xing \& Whitman, 1987). The inhibition of the enzyme AHAS in bacteria for the imidazolinones was reported by Schloss et al. (1985).

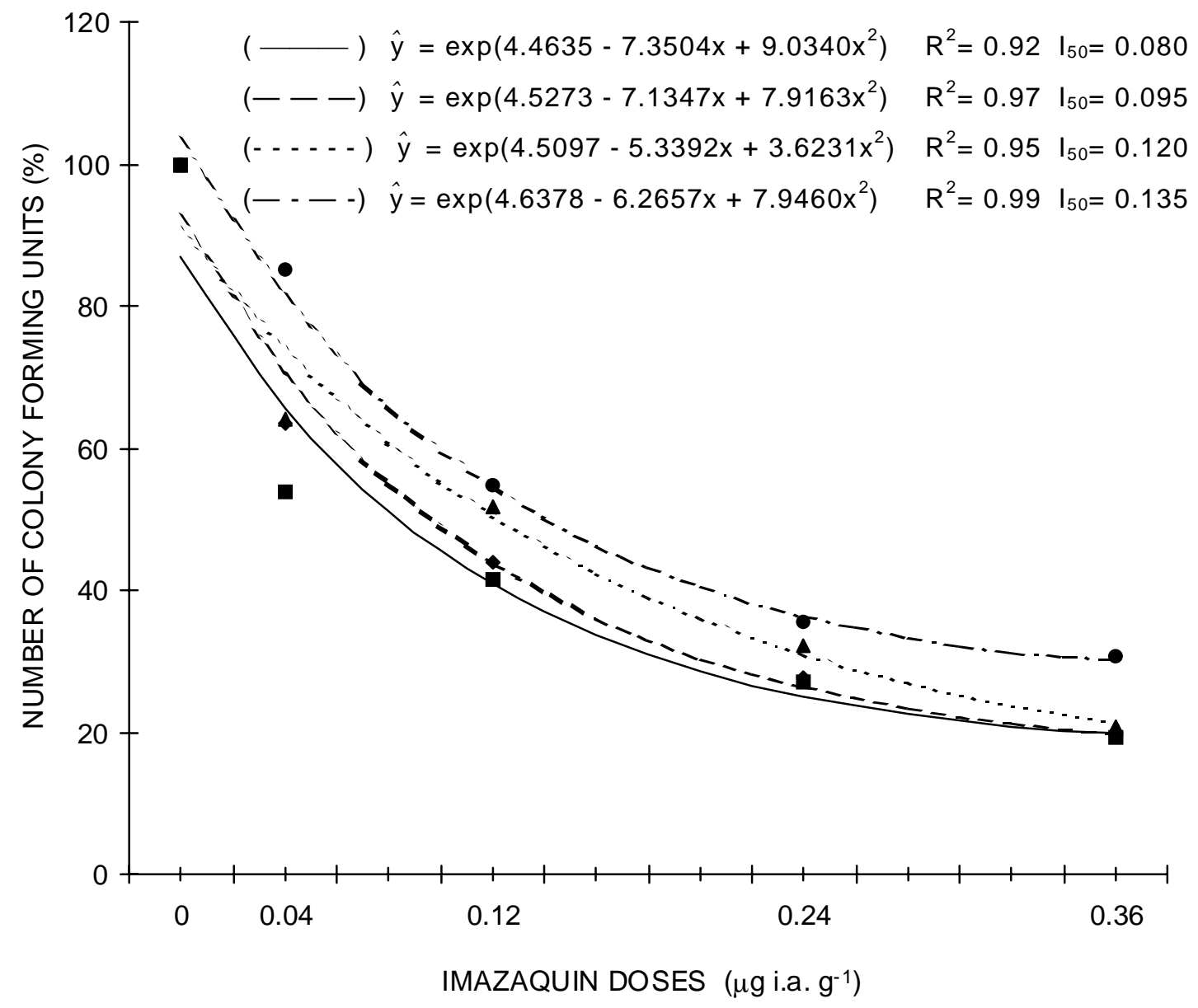

Figure 1 - "In vitro" growth of rhizobium strains, expressed in percentage of control, SEMIA 5073 ( and-), SEMIA 5074 and — - ), SEMIA 5079 ( $\Delta$ and - - - ) and 5080 ( and _ - _ -), as a function of imazaquin doses. 
The clomazone reduced drastically the rhizobium strains CFU number. There was a significant decrease in the CFU number for all rhizobium strains, as a function of the increment in the clomazone rate (Table 2), showing good coefficients of determination $\left(\mathrm{R}^{2}>0.93\right)$ (Figure 2).

Table 2 - Number of colony forming units (CFU) of Bradyrhizobium japonicum strains from bacterial dilution $10^{-5}$, SEMIA 5080, SEMIA 5079, SEMIA 5074 and SEMIA 5073, as a function of clomazone doses

\begin{tabular}{|c|r|r|r|c|}
\hline \multirow{2}{*}{$\begin{array}{c}\text { DOSE } \\
\left(\mu \mathrm{g} \mathrm{a.i.} \mathrm{g}^{-1}\right)\end{array}$} & \multicolumn{4}{|c|}{$\mathrm{CFU}\left(\mathrm{x} 10^{7} \mathrm{ml}^{-1}\right)$} \\
\cline { 2 - 5 } & \multicolumn{1}{|c|}{5080} & \multicolumn{1}{|c|}{5079} & \multicolumn{1}{c|}{ 5074 } & S 5073 \\
\hline 0.0 & $1.460 \mathrm{Aa}$ & $264 \mathrm{Ab}$ & $115 \mathrm{Ad}$ & $168 \mathrm{Ac}$ \\
0.4 & $1.150 \mathrm{AB}$ & $160 \mathrm{Bb}$ & $76 \mathrm{Bc}$ & $118 \mathrm{Bbc}$ \\
0.8 & $860 \mathrm{Ba}$ & $113 \mathrm{Cb}$ & $48 \mathrm{Cc}$ & $64 \mathrm{Cc}$ \\
1.6 & $350 \mathrm{Ca}$ & $83 \mathrm{Db}$ & $35 \mathrm{Dc}$ & $52 \mathrm{Dc}$ \\
3.2 & $320 \mathrm{Ca}$ & $53 \mathrm{~Eb}$ & $31 \mathrm{Db}$ & $43 \mathrm{~Eb}$ \\
\hline
\end{tabular}

- Numbers followed by the same capital letters in the column and same small letters in the line do not differ significantly $(\mathrm{P} \leq 0,05)$ by the Duncan's test.

The indexes of reduction of $50 \%$ on the CFU number $\left(\mathrm{I}_{50}\right)$ produced by clomazone were $0.68 \mu \mathrm{g}$ a. i. $\mathrm{g}^{-1}$, for the strains SEMIA 5073 and SEMIA 5074, and 0.70 and $0.77 \mu \mathrm{g}$ a.i. $\mathrm{g}$ ${ }^{1}$, for the strains SEMIA 5079 and SEMIA 5080, respectively. Those results showed that rates which reduced $50 \%$ of the growth or survival of the strains were lower than the recommended rate for the soybean culture, i.e., $0.85 \mu$ g a.i. $\mathrm{g}^{-1}$ (Figure 2). The strains presented a differential behavior in the growth or survival in vitro for the clomazone, showing the following order of tolerance SEMIA 5074 = SEMIA $5073<$ SEMIA $5079<$ SEMIA 5080. The tolerance of the rhizobium strains to clomazone was similar to the effect produced by imazaquin, just differing for having the strains SEMIA 5073 and SEMIA 5074 show the same tolerance to clomazone (Figure 2). It was verified that clomazone behavior in the growth or survival of the four rhizobium strains presented a similar effect, with very close indexes of $I_{50}$ among the strains. The clomazone reduced the growth of the strains in vitro.

Clomazone applied to susceptible plants inhibits the biosynthesis of the isoprenoids compounds precursors of the photosynthetic pigments, causing an inhibition of the terpenoid metabolism, interfering not only in the carotenoids and phytol accumulation, but also in other compounds of membrane, hormones and growth inhibitor (Argenta \& Lopes, 1992). It is possible that clomazone can inhibit the synthesis of geranyl-geranyl pyrophosphate, precursor of the gibberellins synthesis (Duke \& Kenyon, 1986).

Marenco et al. (1993) verified reductions in the nodulation and in the fixation of dinitrogen of the soybean treated with clomazone. They attributed those effects to reduction in plant growth and not in the growth of Bradyrhizobium, even so without eliminating the possibility of some direct effect of the clomazone on the growth or survival of the rhizobium. However, the results obtained showed that clomazone interferes directly on the growth or survival of all strains tested.

Sulfentrazone strongly reduced the growth or survival of the rhizobium strains analyzed (Table 3). There was a significant reduction in the number of colonies with the increased sulfentrazone rate, presenting high coefficients of determination $\left(\mathrm{R}^{2}>0,95\right)$ (Figure 3$)$. The indexes of reduction of $50 \%$ in the growth or survival of the number of colonies $\left(\mathrm{I}_{50}\right)$ were of $0.30,0.48,0.22$, and $0.27 \mu \mathrm{g}$ a.i. $\mathrm{g}^{-1}$ for the strains SEMIA 5073, SEMIA 5074, SEMIA 5079 and SEMIA 5080, respectively. These results show that the rates that reduced $50 \%$ of the growth of the strains were below the recommended rate for the soybean culture, i.e., $0.42 \mu \mathrm{g}$ a.i. $\mathrm{g}^{-1}$. There was a differential behavior among strains relative to the growth in vitro for the sulfentrazone, exhibiting the following order of tolerance SEMIA 5079 < SEMIA $5080<$ SEMIA 5073 < SEMIA 5074.

Rhizobium strains tolerance to sulfentrazone differed from those to the herbicides imazaquin and clomazone. The strains SEMIA 5079 and SEMIA 5080 presented low tolerance to sulfentrazone, with those two strains being the most tolerant to the treatments with imazaquin and clomazone. On the other hand, the strains SEMIA 5073 and SEMIA 5074 were the most tolerant to the herbicide sulfentrazone, although they have also shown low tolerance to the herbicides imazaquin and clomazone. 


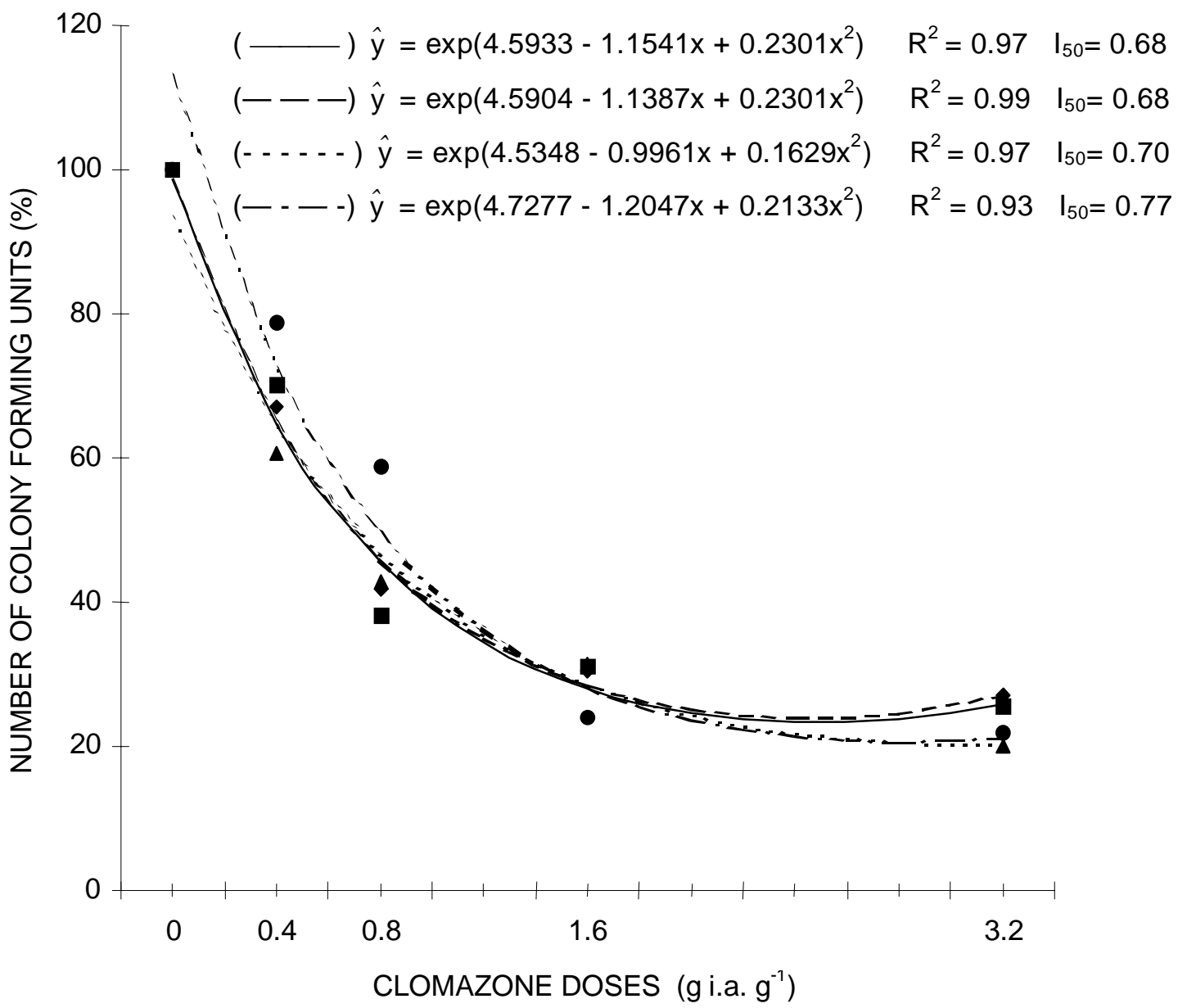

Figure 2 - "In vitro" growth of rhizobium strains, expressed in percentage of control, SEMIA 5073

and $\longrightarrow$, SEMIA 5074 and — - - ), SEMIA 5079

( $\mathbf{\Delta}$ and - - - ) and SEMIA 5080 and - - - -), as a function of clomazone doses.

Table 3 - Number of colony forming units (CFU) of Bradyrhizobium japonium strains from bacterial dilution $10^{-5}$, SEMIA 5080, SEMIA 5079, SEMIA 5074 and SEMIA 5073, as a function of sulfentrazone doses

\begin{tabular}{|c|c|r|r|r|}
\hline \multirow{2}{*}{$\begin{array}{c}\text { DOSE } \\
\left(\mu \mathrm{g} \mathrm{a.i.}^{-1}\right)\end{array}$} & \multicolumn{4}{|c|}{ CFU $\left(\times 10^{7} \mathrm{ml}^{-1}\right)$} \\
\cline { 2 - 5 } & S 5080 & S 5079 & S 5074 & S 5073 \\
\hline 0.0 & $1.320 \mathrm{Aa}$ & $215 \mathrm{Ab}$ & $122 \mathrm{Ac}$ & $136 \mathrm{Ac}$ \\
0.2 & $700 \mathrm{Ba}$ & $121 \mathrm{Bb}$ & $78 \mathrm{Bc}$ & $74 \mathrm{Bc}$ \\
0.4 & $460 \mathrm{Ca}$ & $61 \mathrm{Cb}$ & $64 \mathrm{Cb}$ & $54 \mathrm{Cb}$ \\
0.8 & $390 \mathrm{CDa}$ & $36 \mathrm{Db}$ & $49 \mathrm{Db}$ & $36 \mathrm{Db}$ \\
1.6 & $320 \mathrm{Da}$ & $22 \mathrm{~Eb}$ & $36 \mathrm{~Eb}$ & $25 \mathrm{~Eb}$ \\
\hline
\end{tabular}

- Numbers followed by the same capital letters in the column and same small letters in the line do not differ significantly $(\mathrm{P} \leq 0,05)$ by the Duncan's test.
The sulfentrazone inhibits the protoporphyrinogen oxidase (protox) enzyme in susceptible plants (Dayan et al., 1997), with oxidation of tissues, causing the death of the plants. In microorganisms, the sulfentrazone mechanism of action is still unknown. However, it can be speculated, by analogy with green plants, that sulfentrazone inhibited enzymatic processes in the rhizobium strains.

The three herbicides inhibited the growth of all rhizobium strains, showing a significant decrease on the CFU number, as a function of herbicide rates. However, those strains exhibited different herbicide tolerances. 


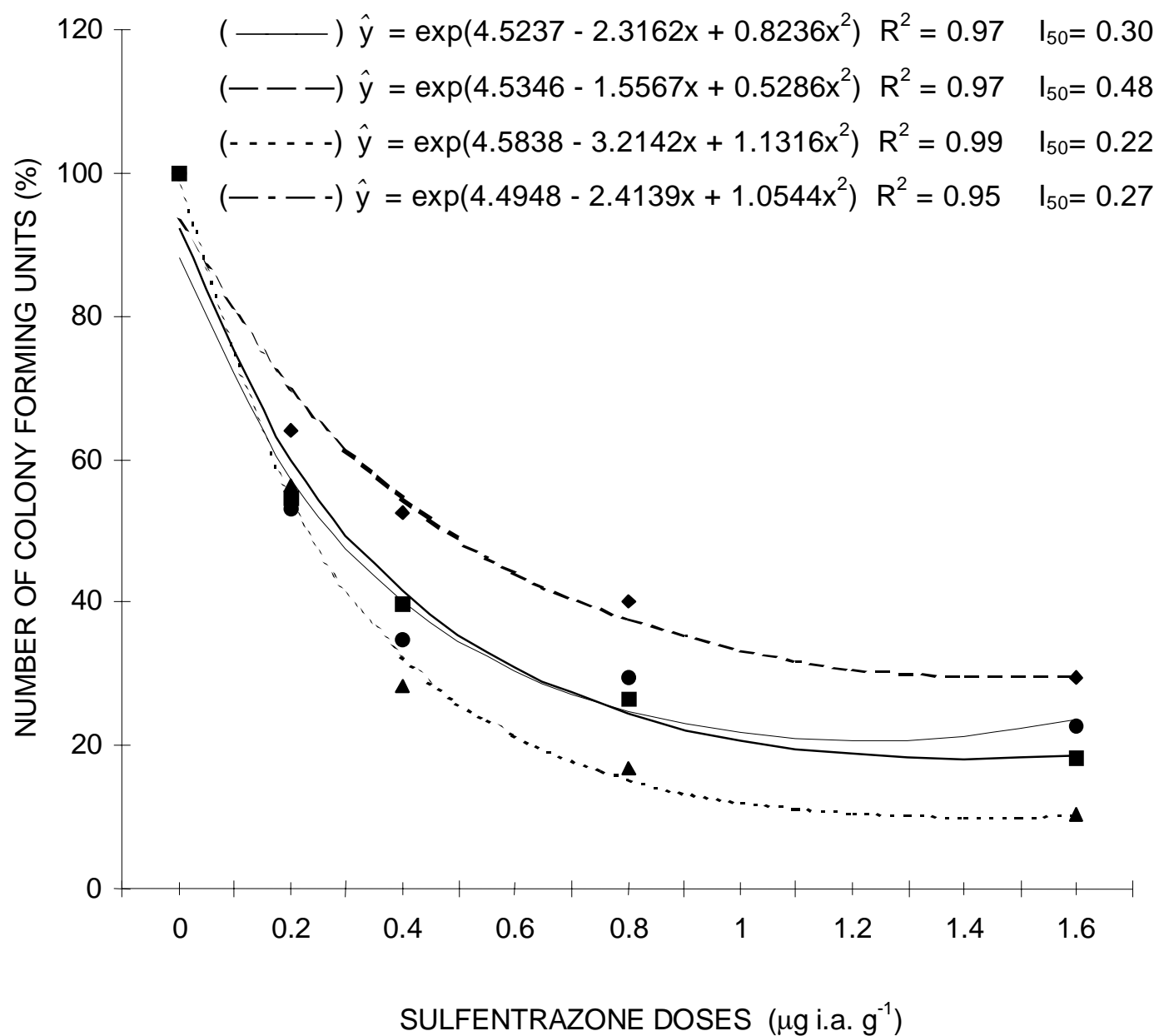

Figure 3 - "In vitro" growth of rhizobium strains, expressed in percentage of control, SEMIA 5073

and - , SEMIA

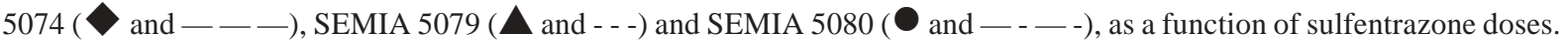

The rates that reduce the rhizobium growth or survival in $50 \%\left(\mathrm{I}_{50}\right)$ were below the rates used for soybean crop. Sulfentrazone $\mathrm{I}_{50}$ was lower than of imazaquin and clomazone $\mathrm{I}_{50}$.

\section{REFERENCES}

ALAGAWAGI, A.R.; REDDY, T.R.K. Effect of trifluralin on Rhizobium and its nodulation on groundnut. Pesticide, v.19, p.38-39, 1985.

ARGENTA, L.C.; LOPES, N.F. Pigments accumulation, photosynthetic, respiratory and growth rates in soybean, rice and water-grass as effected by clomazone rates. R. Bras. Fisiol. Veg., v.4, p.81-86, 1992.
BAUERLE, R.H.; FREUNDLICH, M.; STORMER, F.C.; UMBARGER, H.E. Control of isoleucine, valine and leucine biosynthesis. II. Endproduct inhibition by valine of acetohydroxy synthase in Salmonella ryphimurium. Biochem. Biophys. Acta, v.92, p.142, 1969.

BOLLICH, P.K.; DUNIGAN, E.P.; KITCHEN, L.M.; TAYLOR, V. The influence of trifluralin and pendimethalin on nodulation, $\mathrm{N}_{2}\left(\mathrm{C}_{2} \mathrm{H}_{2}\right)$ fixation, and seed yield of field grown soybeans (Glycine max). Weed Science, v.36, p.15-19, 1988.

BORGES, A.C.; GUIMARÃES, W.V.; MUCHOVEJ, R.M.C.; GONZALES, G.R. Resistance of Bradyrhizobium japonicum strains to different fungicides and herbicides. World J . Microbiol. Biotechnol., v.6, p.428-430, 1990. 
BROCK, J.L. Effects of the herbicides trifluralin and carbetamide on nodulation and growth of legumes seedlings. Weed Res., v.12, p.150-154, 1972 .

DAYAN, E.F.; DUKE, O.S.; REDDY, K.N.; HAMPER B.C., LESCHINSKY, K.L. Effects of isoxalizoles on protoporphyrinogen oxidase and porphyrin physiology. J . Agric. Food Chem., v.52, p.967975, 1997.

DEUBER, R.; CAMARGO, P.N.; SIGNORI, L.H. Efeitos de herbicidas e populações de plantas na nodulação e produção de soja (Glycine max L.) Merrill, Santa Rosa. Planta Daninha, v.4, p.97-109, 1981.

DUKE, S.O.; KENYON, W.H, Effects of dimethazone (FMC 57020) on chloroplast development. II Pigment synthesis and photosynthetic function in cowpea (Vigna unguiculata L.) primary leaves. Pestic. Biochem. Physiol., v.25, p.11-18, 1986.

EOYANG, L.; SILVERMAN, P. Purification and subunit composition of acetohydroxy acid synthase I from Escherichia coli K-12. J. Bacteriol., v.157, p.184-189, 1984.

KISHINEVSKI, B.; LOBEL, R.; LIFSHITZ, N.; GURFEL, D. Effects of some commercial herbicides on rhizobia and their symbiosis with peanuts. Weed Res., v.28, p.291-296, 1988

MALLIK, M.A.B.; TESFAI, K. Pesticidal effect on soybean-rhizobia symbiosis. Plant Soil, v.85, p.33-41, 1985.

MARENCO, R.A.; LOPES, N.F.; MOSQUIM, P.R. Nodulation and nitrogen fixation in soybeans treated with herbicides. R. Bras. Fisiol. Veg., v.5, p.121-126, 1993.

MOORMAN, T.B. Effects of herbicides on the survival of Rhizobium japonicum strains.Weed Sci., v.34, p.628-633, 1986.
PETERS, E.J.; ZBIBA, M.B. Effects of herbicides on nitrogen fixation of alfalfa (Medicago sativa) and red clover (Trifolium pratense). Weed Sci., v.27, p.18-21, 1979.

RAY, T.B. Site of action of chlorsulfuron: inibition of valine and isoleucine byosinthesis in plant. Plant Physiol., v.73, p.827-831, 1984.

ROMEIRO, R.S. Correlação entre turbidez e número de células viáveis em suspensão bacteriana. Viçosa: UFV/ DFP/ FIP-640, 1996. 9p. (Apostila)

SHANER, D.L.; ANDERSON, P.C.; STIDHAM, M.A. Imidazolinones, potent inhibitors of acetohydroxyacid sinthase. Plant Physiol., v.76, p.645-646, 1984

SCHLOSS, J.V.; VAN DYKE, D.E.; VASTA, J.F.; KUTNY, R.M. Purification and properties of Salmonella typhimurium acetolactate synthase isozyme II from Escherichia coli HB101/pDU9. Biochemystry, v.24, p.4952, 1985.

SUTTON, A.; NEWMAN, T.; FRANCIS, M.; FREUNDLICH, M. Valine-resistant Escherichia coli K-12 strains with mutations in the ilvB operon. J . Bacteriol., v.148, p.998, 1981.

THURLOW, D.L.; HILTBOLD, A.E. Dinitrogen fixation by soybeans in Alabama. Agron. J ., v.77, p.432-436, 1985.

VARELA, R.; CRUZ, R. Efecto de algunas dinitroanilinas sobre la nodulación de la soja (Glycine $\max ($ L.) Merr.). R. Inst. Col. Agropec., v.19, p.17-23, 1984.

VINCENT, J.M. A manual for the practical study of the root-nodule bacteria. Oxford: Blackwell, 1970. 164p.

XING, R.Y.; WHITMAN, W.B. Sulfometuron methyl - sensitive and - resistant acetolactate synthases of the archaebacterium Methanococus spp. J . Bacteriol., v.169, p.4486-4492, 1987. 